\title{
Miniplegia versus blood cardioplegia in elective aortic valve replacement: a prospective randomised, non - inferiority controlled trial
}

\author{
Eduardo Bernabeu*, Antonio García-Valentín, Juan Meseguer, Aquilino Hurlé, Patricio Llamas \\ From World Society of Cardiothoracic Surgeons 25th Anniversary Congress, Edinburgh \\ Edinburgh, UK. 19-22 September 2015
}

\section{Background/Introduction}

Antegrade intermittent 4:1 blood cardioplegia with Buckberg solution is widely used in elective aortic valve replacement. Use of miniplegia could simplify myocardial protection in this setting.

\section{Aims/Objectives}

Our objective was to compare both strategies in terms of non-inferiority.

\section{Method}

A prospective, randomised controlled trial was performed. Primary end-point was demonstrating noninferiority of miniplegia versus intermittent $4: 1$ blood cardioplegia in elective aortic valve replacement. For sample size calculation, a maximum increase $+15 \%$ in mean peak postoperative troponin $\mathrm{T}$ was considered non-inferior $(\Delta=+474.24 \mathrm{ng} / \mathrm{L})$. Power was 0.9 , and $\alpha$ $<0.05$ was considered statistically significant. Secondary end-points were differences in troponin curve, reperfusion and postoperative rhythm, haematocrit, use of inotropic and vasopressor drug support, ICU stay, and postoperative evolution.

\section{Results}

66 patients were enrolled and randomised. There were no significant differences in baseline and preoperative variables. Peak troponin $\mathrm{T}$ in miniplegia group was noninferior to blood cardioplegia group $(\mathrm{p}=0.036)$. Patients in the miniplegia group showed a higher incidence of spontaneous sinus rhythm after myocardial ischemia $(18 / 33,54.5 \%$ versus $8 / 33,24.2 \%, \mathrm{p}=0.005)$ and fewer

Dept. Cardiac Surgery, Hospital General Universitario de Alicante, Alicante, E03010, Spain patients required defibrillation $(9 / 33,27.7 \%$ versus $21 /$ $33,63.6 \%, \mathrm{p}=0.03)$ for ventricular reperfusion arrhythmias. Postoperatively, there were no differences in troponin $\mathrm{T}$ release, inotropic and vasopressor drug support, ICU stay, and postoperative mortality.

\section{Discussion/Conclusion}

Miniplegia used as myocardial protection in elective aortic replacement is non-inferior to blood cardioplegia. Preferential return to sinus rhythm and lower incidence of reperfusion arrhythmias in the miniplegia group could reflect a better myocardial protection during cardioplegic arrest. Ease of administration and inexpensive use of miniplegia are additional benefits.

\section{Published: 16 December 2015}

doi:10.1186/1749-8090-10-S1-A60

Cite this article as: Bernabeu et al:: Miniplegia versus blood cardioplegia in elective aortic valve replacement: a prospective randomised, non inferiority controlled trial. Journal of Cardiothoracic Surgery 2015

10(Suppl 1):A60.

Submit your next manuscript to BioMed Central and take full advantage of:

- Convenient online submission

- Thorough peer review

- No space constraints or color figure charges

- Immediate publication on acceptance

- Inclusion in PubMed, CAS, Scopus and Google Scholar

- Research which is freely available for redistribution

Submit your manuscript at www.biomedcentral.com/submit
() Biomed Central 